\title{
Methyl chavicol: characterization of its biogenic emission rate, abundance, and oxidation products in the atmosphere
}

\author{
N. C. Bouvier-Brown ${ }^{1}$, A. H. Goldstein ${ }^{1}$, D. R. Worton ${ }^{1}$, D. M. Matross ${ }^{1}$, J. B. Gilman ${ }^{2}$, W. C. Kuster ${ }^{2}$, D. Welsh-Bon ${ }^{2}$, \\ C. Warneke ${ }^{2}$, J. A. de Gouw ${ }^{2}$, T. M. Cahill ${ }^{3}$, and R. Holzinger ${ }^{4}$ \\ ${ }^{1}$ Department of Environmental Science, Policy, and Management, University of California Berkeley, Berkeley, CA, USA \\ ${ }^{2}$ NOAA Earth System Research Laboratory \& Cooperative Institute for Research in Environmental Sciences, \\ University of Colorado at Boulder, CO, USA \\ ${ }^{3}$ Division of Mathematical and Natural Sciences, Arizona State University, West Campus, Phoenix, AZ, USA \\ ${ }^{4}$ Institute for Marine and Atmospheric Research, Utrecht University, Utrecht, The Netherlands
}

Received: 26 September 2008 - Published in Atmos. Chem. Phys. Discuss.: 19 November 2008

Revised: 16 February 2009 - Accepted: 5 March 2009 - Published: 23 March 2009

\begin{abstract}
We report measurements of ambient atmospheric mixing ratios for methyl chavicol and determine its biogenic emission rate. Methyl chavicol, a biogenic oxygenated aromatic compound, is abundant within and above Blodgett Forest, a ponderosa pine forest in the Sierra Nevada Mountains of California. Methyl chavicol was detected simultaneously by three in-situ instruments - a gas chromatograph with mass spectrometer detector (GC-MS), a proton transfer reaction mass spectrometer (PTR-MS), and a thermal desorption aerosol GC-MS (TAG) - and found to be abundant within and above Blodgett Forest. Methyl chavicol atmospheric mixing ratios are strongly correlated with 2-methyl-3-buten2-ol (MBO), a light- and temperature-dependent biogenic emission from the ponderosa pine trees at Blodgett Forest. Scaling from this correlation, methyl chavicol emissions account for $4-68 \%$ of the carbon mass emitted as MBO in the daytime, depending on the season. From this relationship, we estimate a daytime basal emission rate of 0.72 $10.2 \mu \mathrm{gCg}^{-1} \mathrm{~h}^{-1}$, depending on needle age and seasonality. We also present the first observations of its oxidation products (4-methoxybenzaldehyde and 4-methyoxy benzene acetaldehyde) in the ambient atmosphere. Methyl chavicol is a major essential oil component of many plant species. This work suggests that methyl chavicol plays a significant role in the atmospheric chemistry of Blodgett Forest, and potentially other sites, and should be included explicitly in both biogenic volatile organic carbon emission and atmospheric chemistry models.
\end{abstract}

\section{Correspondence to:}

N. C. Bouvier-Brown

(nbouvier@nature.berkeley.edu)

\section{Introduction}

Plants contain thousands of different volatile and semivolatile organic compounds (Adams, 2007), and the atmospheric chemistry community has historically focused on a small subset of these. With continuing improvements in analytical instrumentation, a wider suite of biogenic volatile organic compounds (BVOCs) have been measured in the atmosphere in recent years (e.g. Goldan et al., 1993; Schade and Goldstein, 2001; Helmig et al., 2007), and the list of specific BVOCs included in emission inventories and atmospheric chemistry models is growing (e.g. Sakulyanontvittaya et al., 2008; Steiner et al., 2008). Here we focus on methyl chavicol (IUPAC name: 1-methoxy-4(2-propenyl)-benzene; CAS\# 140-67-0), a compound previously uncharacterized in the atmosphere. Also known as estragole or 4-allylanisole, methyl chavicol $\left(\mathrm{C}_{10} \mathrm{H}_{12} \mathrm{O}\right)$ is an oxygenated aromatic BVOC, and although it has 10 carbon atoms, it is not a terpenoid compound. Plants synthesize this compound, which smells like licorice, from the amino acid phenylalanine via the shikimate pathway (Sangwan et al., 2001) (Fig. 1). Analysis of extracted plant oils show that methyl chavicol is produced by a variety of plants (Table 1). For example, methyl chavicol is a major essential oil component of many common herbs such as basil (up to 70\%) (Simon et al., 1990; Leung and Foster, 1996; Sajjadi, 2006), tarragon (up to 86\%) (Werker et al., 1994; Leung and Foster, 1996; De Vincenzi et al., 2000), and fennel (up to 65\%) (Barazani et al., 2002; De Vincenzi et al., 2000). It is also a major component in the oils of culturally-significant plants found worldwide, including a Latin American herb (up to 97\%) (Ciccio, 2004), an ubiquitous Korean herb (up to 49\%) (Shin and Kang, 2003),

Published by Copernicus Publications on behalf of the European Geosciences Union. 


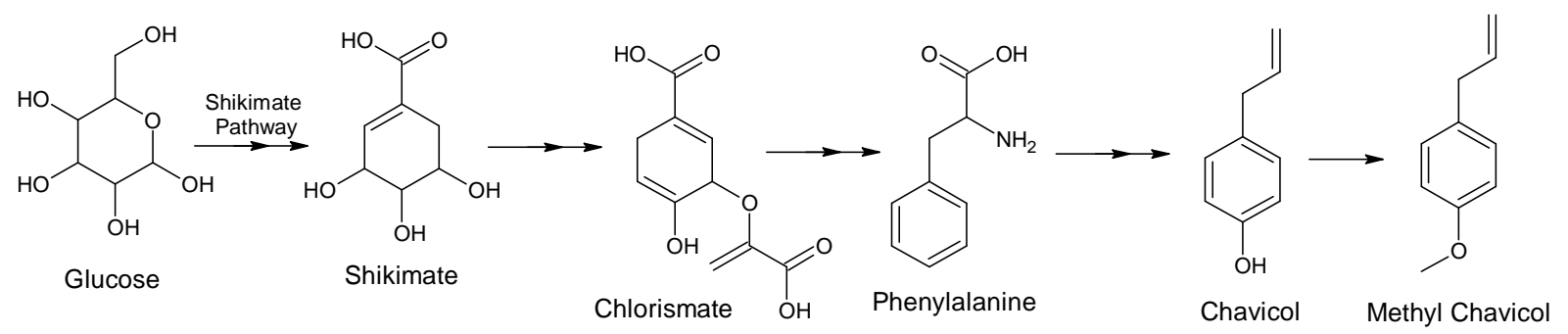

Fig. 1. Schematic of methyl chavicol synthesis modified from the glucose $\rightarrow$ phenylalanine and phenylalanine $\rightarrow$ methyl chavicol mechanisms presented by Yoshida (1969) and Sangwan et al. (2001), respectively.

an Indian herb (up to 93\%) (Hazarika and Nath, 1995), a Turkish herb (up to 90\%) (Kaya et al., 2007), and a Mexican avocado (up to 95\%) (Pino et al., 2006b; Leung and Foster, 1996). Methyl chavicol has been identified in the resin of pines (Pinus spp.) (Mirov, 1961; Salom and Hobson, 1995 and references therein), such as Caribbean (Snyder and Bower, 2005), black (Rezzi et al., 2001), Scots, slash (Chadwick and Palkin, 1941), longleaf (Mirov, 1948), lodgepole, loblolly (Strom et al., 2002; Werner, 1972), and ponderosa (e.g. Cobb et al., 1972; Adams and Edmunds Jr., 1989). In fact, studies of ponderosa pine oil show that methyl chavicol accounts for 3-40\% of the total needle oil (Zavarin et al., 1971), an abundance comparable to (Krauze-Baranowka et al., 2002) or higher than the monoterpene 3-carene (Kurose et al., 2007).

In the late 1960s, examination of ponderosa pine trees injured by photochemical air pollution in southern California revealed that some of the damaged trees were also being infested by bark beetles. The most significant difference in the chemical makeup between the healthy and infested trees was the amount of methyl chavicol in their resin (Cobb et al., 1972). Methyl chavicol is an effective behavioral interruptant for a variety of bark beetle species in many different geographic locations, as shown through lab assays of walking behavior (Hayes et al., 1994; Werner, 1995) and field tests of flight behavior (Hayes and Strom, 1994; Joseph et al., 2001; Snyder and Bower, 2005). Although walking or flight responses of some bark beetle species are reduced by methyl chavicol, others species are attracted to it (Werner, 1972; Joseph et al., 2001). Protecting trees with methyl chavicol after artificially encouraging beetle attack was not a successful treatment tactic (Strom et al., 2004), thus it is unclear if methyl chavicol plays a significant role in host colonization behavior by bark beetles. It likely works in concert with other compounds or plays a role in the behavior of only certain species.

Methyl chavicol is volatile enough to be readily emitted from vegetation, but until recently, atmospheric measurements and emission rates have been notably absent in the literature (Lerdau et al. 1997; Fuentes et al., 2000). Methyl chavicol was first measured in the ambient air of a California ponderosa pine forest with proton transfer reaction mass spectrometry (PTR-MS) monitoring $\mathrm{m} / \mathrm{z} 149$ (Holzinger et al., 2005). Subsequent studies using instrumentation with mass spectrometer libraries confirmed the PTR-MS identification (Bouvier-Brown et al., 2007, 2009). Branch enclosure measurements using PTR-MS and solid phase microextraction (SPME) fibers analyzed with ion trap GC-MS identified ponderosa pine as the source plant for methyl chavicol emissions to the Blodgett forest ecosystem and provided estimates of emission rates and ecosystem flux (Bouvier-Brown et al., 2009). Emissions of methyl chavicol were $9-117 \%$ of the total measured terpene (sum of the total measured monoterpenes and sesquiterpenes) flux, but each branch had a different emission profile which varied over time (Bouvier-Brown et al., 2009). As a result of this variation, methyl chavicol basal emissions ranged from 0.159 to $1.09 \mu \mathrm{gCg}$ (dry weight $)^{-1} \mathrm{~h}^{-1}$ and an average daytime ecosystem flux was estimated to be $1.37 \mu \mathrm{mol} \mathrm{m}^{-2} \mathrm{~h}^{-1}$ (Bouvier-Brown et al., 2009).

Methyl chavicol oxidation has been studied in the laboratory using a PTR-MS. Full photochemical oxidation of methyl chavicol in a smog chamber produced a $42 \%$ yield of an unknown compound detected at $\mathrm{m} / \mathrm{z} 137$ and a $23 \%$ yield of a compound, hypothesized to be a $\mathrm{C}_{9} \mathrm{H}_{10} \mathrm{O}_{2}$ aldehyde, detected at $\mathrm{m} / \mathrm{z} 151$ (Lee et al., 2006b). An unidentified product detected at $\mathrm{m} / \mathrm{z} .151$ was also generated from ozonolysis experiments at a $25 \%$ yield, which was the largest $m / z 151$ yield of any terpene tested (Lee et al., 2006a). These experiments also showed that methyl chavicol oxidation leads to the production of secondary organic aerosol (SOA) with yields of $40 \%$ from full photochemical oxidation (Lee et al., 2006b) and 6\% from ozonolysis (Lee et al., 2006a).

Here we report a more detailed characterization of the environmental factors that drive methyl chavicol emissions in Blodgett Forest, a ponderosa pine forest. We also present the first observations of its oxidation products in the ambient atmosphere. To elucidate processes driving methyl chavicol emissions, we compare its mixing ratios and average diurnal profiles to that of 2-methyl-3-buten-2-ol (MBO) and the monoterpene $\alpha$-pinene. MBO, a known prominent biogenic emission from this site, is emitted from the ponderosa pine trees as a function of light and temperature in a similar manner to that of isoprene (Baker et al., 1999; Lamanna and 
Table 1. A variety of plants are known to produce methyl chavicol. Percentage of methyl chavicol present in the plant's essential oil is noted if available. The primary reference describes the measurement and analytical technique; the secondary reference provides numerical data without detailed analytical information.

\begin{tabular}{|c|c|c|c|c|}
\hline Plant species containing methyl chavicol & Common name/description & Oil \% methyl chavicol & Primary reference & Secondary reference \\
\hline Ocimum minimum & basil & $36.3 \%$ & Tchoumbougnang et al. (2006) & \\
\hline Ocimum basilicum L. cv. purple & purple basil from Iran & $52.4 \%$ & Sajjadi (2006) & \\
\hline Ocimum basilicum L. $c v$. green & green basil from Iran & $40.5 \%$ & Sajjadi (2006) & \\
\hline Ocimum basilicum L. (Lamiaceae) & basil (sweet) & $5-43 \%$ & De Vincenzi et al. (2000) & $\begin{array}{l}\text { Salom and Hobson (1995); } \\
\text { Simon et al. (1990) }\end{array}$ \\
\hline Ocimum basilicum L. (Labiatae) & basil (sweet) & $70 \%$ & & $\begin{array}{l}\text { Leung and Foster (1996); } \\
\text { Duke (2001) }\end{array}$ \\
\hline Artemisia dracunculus L. (Asteraceae) & French tarragon & $77-86 \%$ & Werker et al. (1994) & Salom and Hobson (1995) \\
\hline Artemisia dracunculus L. (Asteraceae) & Russian tarragon & $0.1-0.3 \%$ & Werker et al. (1994) & \\
\hline Artemisia dracunculus L. (Asteraceae) & tarragon & $60-81 \%$ & De Vincenzi et al. (2000) & $\begin{array}{l}\text { Leung and Foster (1996); } \\
\text { Duke (2001) }\end{array}$ \\
\hline Foeniculum vulgare var. vulgare & bitter fennel & $3-65 \%$ cultivated/wild & Barazani et al. (2002) & \\
\hline Foeniculum vulgare Mill. (Apiaceae) & sweet fennel & $5-20 \%$ & De Vincenzi et al. (2000) & $\begin{array}{l}\text { Salom and Hobson (1995); } \\
\text { Leung and Foster (1996); } \\
\text { Duke (2001) }\end{array}$ \\
\hline Pimpinella anisum $\mathrm{L}$. & anise & & & Leung and Foster (1996) \\
\hline Pimpinella anisum L. (Apiaceae) & anise vert & $1 \%$ & De Vincenzi et al. (2000) & \\
\hline $\begin{array}{l}\text { Illicium verum Hook.f. } \\
\text { (Magnoliaceae)/(Illiciaceae) }\end{array}$ & star anise & $5-6 \%$ & De Vincenzi et al. (2000) & $\begin{array}{l}\text { Salom and Hobson (1995); } \\
\text { Duke (2001) }\end{array}$ \\
\hline Pimpinella anisum & Mexican spice (grain) & $1-2 \%$ & Ondarza and Sanchez (1990) & \\
\hline $\begin{array}{l}\text { Syzygium aromaticum L. Merrill. } \\
\text { L.M. Perry }\end{array}$ & clove & & & $\begin{array}{l}\text { Salom and Hobson (1995); } \\
\text { Duke (2001) }\end{array}$ \\
\hline $\begin{array}{l}\text { Pimenta racemosa J.W. Moore } \\
\text { (Myrtaceae) }\end{array}$ & West Indian bay & & & Leung and Foster (1996) \\
\hline Origanum majorana L. (Labiatae) & marjoram & & & Leung and Foster (1996) \\
\hline Anthriscus cerefolium Hoffm. (Apiaceae) & chervil & & & Leung and Foster (1996) \\
\hline Backhousia anisata Vickery (Myrtaceae) & sub-tropical Australian tree & $4.4-77.5 \%$ & Brophy and Boland (1991) & \\
\hline Tagetes lucida (Asteraceae) & aromatic herb (Latin America) & Costa Rican: 95-97\% & Ciccio (2004) & \\
\hline Agastache rugosa Kuntze & Korean herb & $42-49 \%$ & Shin and Kang (2003) & \\
\hline Agastache foeniculum & anise hyssop/W.N. American shrub/herb & $96-97 \%$ & Mazza and Kiehn (1992) & Adams (2007) \\
\hline Amomum linguforme & rhizomatous herb (India) & $93.2 \%$ & Hazarika and Nath (1995) & Adams (2007) \\
\hline Clausena dunniana & S. China shrub & $93.1 \%$ & & Adams (2007) \\
\hline Dictamnus gymnostylis & "burning bush"/middle-east bush & $15 \%$ & Fleisher and Fleisher (2004) & \\
\hline Dictamnus hispanicus & endemic to Mediterranean area (Spain) & $79 \%$ & Merle et al. (2006) & \\
\hline Helenium amarum (Raf.) H. Rock & yellowdicks - Cuba, also present in US & $84.4 \%$ & Pino et al. (2006a) & \\
\hline Scandix iberica Bieb. & herb in Turkey & $85.8-90.5 \%$ & Kaya et al. (2007) & \\
\hline Echinops graecus & endemic to Greece & $42.5 \%$ & Papadopoulou et al. (2006) & \\
\hline Ravensara aromatica Sonn. & endemic to Madagascar & $79.7 \%$ & Ramanoelina et al. (2006) & \\
\hline Persea arnericana Mill. (Lauraceae) & Mexican type of avocado & $53.9-95 \%$ & Pino et al. (2006b) & Leung and Foster (1996) \\
\hline Ochrosperma lineare (Myrtaceae) & Straggley Baeckea (Australia) & $81.6 \%$ & Southwell et al. (2003) & \\
\hline Pinus caribaea Morelet & Caribbean pine & $1.5-3 \%$ & Snyder and Bower (2005) & Salom and Hobson (1995) \\
\hline Pinus nigra Arnold & black pine & $0-1.3 \%$ & Rezzi et al. (2001) & Salom and Hobson (1995) \\
\hline Pinus sylvestris $\mathrm{L}$. & Scots pine & & & Salom and Hobson (1995) \\
\hline Pinus elliotti var elliotti & slash pine & $5-13 \%$ & Chadwick and Palkin (1941) & $\begin{array}{l}\text { Salom and Hobson (1995); } \\
\text { Mirov (1961) }\end{array}$ \\
\hline Pinus elliotti var densa & (Florida) & $3 \%$ & & Mirov (1961) \\
\hline Pinus palustris Mill & longleaf pine, southern yellow pine & $1-5 \%$ & & $\begin{array}{l}\text { Salom and Hobson (1995); } \\
\text { Hayes et al. (1994) }\end{array}$ \\
\hline Pinus palustris Mill & longleaf pine (Southern US) & $0-0.7 \%$ & Mirov (1948) & Mirov (1961) \\
\hline Pinus taeda $\mathrm{L}$. & loblolly pine (South Eastern US) & $1-11 \%$ & $\begin{array}{l}\text { Sutherland and Welles (1956); } \\
\text { Werner (1972) }\end{array}$ & $\begin{array}{l}\text { Salom and Hobson (1995); } \\
\text { Mirov (1961) }\end{array}$ \\
\hline Pinus taeda $\mathrm{L}$. & loblolly pine & $\begin{array}{r}0.22-2.5 \% \\
\text { oleoresin weight }\end{array}$ & Strom et al. (2002) & \\
\hline Pinus contorta Dougl. & lodgepole pine & & Nebeker et al. (1995) & Joseph et al. (2001) \\
\hline Pinus hartwegii & (upper elevations Mexico) & $3 \%$ & Mirov (1961) & \\
\hline Pinus lumholtzii & (western Mexico) & $2-3 \%$ & & Mirov (1961) \\
\hline Pinus michoacana & (Mexico) & $2-3 \%$ & Mirov (1961) & \\
\hline Pinus patula & (Mexico) & $5 \%$ & Mirov (1961) & \\
\hline Pinus jeffriyi & Jeffrey pine (Western US) & & & Mirov (1961) \\
\hline Pinus ponderosa & ponderosa pine & $7.4-25.7 \%$ & Cobb et al. (1972) & \\
\hline Pinus ponderosa & ponderosa pine & $8 \%$ & Krauze-Baranowska et al. (2002) & \\
\hline Pinus ponderosa & ponderosa pine & present & Himejima et al. (1992) & \\
\hline Pinus ponderosa & ponderosa pine & $0.4-5.3 \%$ & Adams and Edmunds (1989) & \\
\hline Pinus ponderosa & ponderosa pine & $3-40 \%$ & Zavarin et al. (1971) & \\
\hline Pinus ponderosa & ponderosa pine & $10.50 \%$ & Kurose et al. (2007) & \\
\hline Pinus ponderosa & ponderosa pine & $0-2 \%$ depend on location & Mirov (1961) & \\
\hline
\end{tabular}


Goldstein, 1999; Schade et al., 2000; Schade and Goldstein, 2001; Gray et al., 2005). $\alpha$-Pinene is a significant contributor to the monoterpene flux out of this forest, and like other monoterpenes at this site, it is emitted as a function of temperature (Shade et al., 1999; Schade and Goldstein, 2003; Lee et al., 2005; Holzinger et al., 2005, 2006).

\section{Experimental}

\subsection{The site}

Methyl chavicol was measured at the Blodgett Forest Ameriflux site, a ponderosa pine plantation owned by Sierra Pacific Industries, located on the western slope of the Sierra Nevada Mountains of California $\left(38.90^{\circ} \mathrm{N}, 120.63^{\circ} \mathrm{W}\right.$, and 1315 m elevation) as a part of BEARPEX ( $B$ iosphere $E$ ffects on AeRosols and Photochemistry EXperiment) 2007. The site's vegetation is dominated by an overstory of ponderosa pine (Pinus ponderosa L.) with an average height of $8 \mathrm{~m}$ and an understory of manzanita (Arctostaphylos spp.) and whitethorn ceanothus (Ceanothus cordulatus) shrubs. Mixing ratios and fluxes of carbon dioxide, water vapor, and ozone, along with meteorological parameters, have been measured at the site since 1997, and are reported in detail elsewhere (e.g. Goldstein et al., 2000; Bauer et al., 2000).

BEARPEX included two distinctly different meteorological periods. The first period from 20 August to 12 September (day of year 232-255) was characterized by warm and dry conditions (average daytime meteorological parameters: temperature $27^{\circ} \mathrm{C}$, relative humidity $26 \%$, and maximum photosynthetically active radiation (PAR) $1410 \mu \mathrm{mol} \mathrm{m}^{-2} \mathrm{~s}^{-1}$ ). The second period from 13 September to 10 October (day of year 256-283) was characterized by cool and wet conditions (average daytime meteorological parameters: temperature $15^{\circ} \mathrm{C}$, relative humidity $49 \%$, and PAR $1010 \mu \mathrm{mol} \mathrm{m}^{-2} \mathrm{~s}^{-1}$ ). Figure 2 shows the temperature and rainfall time series during BEARPEX and highlights the measurement periods for the gas chromatography techniques described below.

\subsection{Analytical techniques}

\subsubsection{Berkeley GC-MS}

The gas chromatograph with quadrupole mass spectrometer (GC-MS) instrument described by Millet et al. (2005) was optimized to quantify $\mathrm{C}_{10}-\mathrm{C}_{15}$ biogenic compounds with the redesign of the inlet system described here. Methyl chavicol was never reliably observed at Blodgett Forest during the 10 years of sampling until these modifications were made. To reduce sample loss due to condensation, all tubing and fittings prior to the $\mathrm{GC}$ oven were heated to $\sim 50^{\circ} \mathrm{C}$ (Omega Engineering Stamford, CT) and the sub-zero water trap was eliminated. With ambient water vapor in the sample, the hydrocarbon preconcentration trap packed with Tenax TA

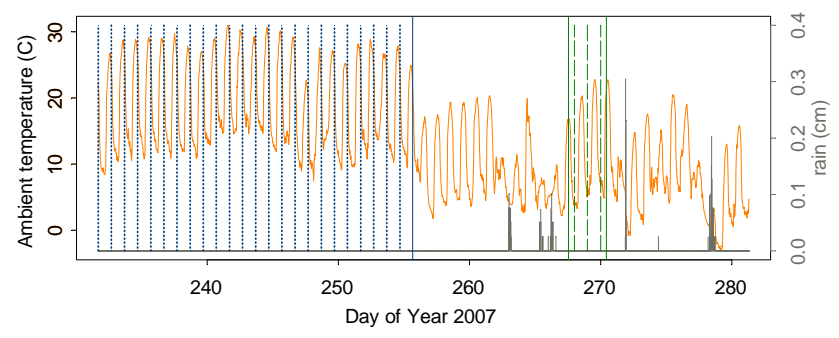

Fig. 2. A timeline showing the temperature (orange -) and rainfall patterns (solid grey bars) during BEARPEX. The shaded region (blue) corresponds to the time when the Berkeley GC-MS was measuring at $1.5 \mathrm{~m}$ above the forest floor (day of year 231-255), while the un-shaded region corresponds to the time when the Berkeley GC-MS was sampling from $9.3 \mathrm{~m}$ above the forest floor (day of year 255-281). The dashed area (green) marks the 3 days (day of year 267.5-270.4) when the Berkeley GC-MS and the NOAA GC-MS were co-located at $9.3 \mathrm{~m}$.

remained at ambient temperature during sample collection. All tubing and fittings were changed from PTFE (Oakland Valve and Fitting, Inc., Fremont, CA) to Silcosteel (Restek Corporation, Bellefonte, PA) because the metal tubing allows for even heat dispersal and the internally passivated surface minimizes wall reactions and subsequent losses. To reduce the chance of sample adsorption, the chemically-active ozone trapping material was changed from impregnated glass wool to a $1 \mu \mathrm{m}$ pore size Pall A/E glass fiber filter (VWR, Ann Arbor, MI). This filter was coated with sodium thiosulfate (Sigma-Aldrich, St. Louis, MO), following Pollmann et al. (2005), and housed in a heated stainless steel filter holder (Cole-Parmer, Vernon Hills, IL). The filter was also used to remove particulate matter from the sample. To ensure its effectiveness, the ozone filter was changed at least once per day.

Ambient air was pulled through $6.35 \mathrm{~mm}$ outer diameter Silcosteel tubing at $\sim 4 \mathrm{~L} \mathrm{~min}^{-1}$, scrubbed of ozone, and subsampled through $3.18 \mathrm{~mm}$ outer diameter Silcosteel tubing at $\sim 20 \mathrm{~mL} \mathrm{~min}^{-1}$. Once per hour, a $600 \mathrm{~mL}$ sample was collected over a $30 \mathrm{~min}$ period. The pre-concentrated sample was heated from ambient temperature to $220^{\circ} \mathrm{C}$ within $10 \mathrm{~s}$ to desorb the trapped compounds into ultra high purity helium carrier gas and transferred to the head of the chromatographic column $(30 \mathrm{~m} \times 0.25 \mathrm{~mm} \times 0.25 \mu \mathrm{m}$ phase thickness, Rtx-5; Restek Corporation). The GC oven temperature was held at $43^{\circ} \mathrm{C}$ for $4.25 \mathrm{~min}$, increasing to $160^{\circ} \mathrm{C}$ at $5^{\circ} \mathrm{C} \mathrm{min}^{-1}$, then to $220^{\circ} \mathrm{C}$ at $10^{\circ} \mathrm{C} \mathrm{min}^{-1}$ and held at this temperature for $11.75 \mathrm{~min}$. The mass spectrometer (HP 5971) was operated in single ion mode, and methyl chavicol was quantified with $\mathrm{m} / \mathrm{z} 148$.

Since methyl chavicol is a semi-volatile compound, it is not readily available as a gas phase standard. Bouvier-Brown et al. (2007) produced a gas phase methyl chavicol standard by volatilizing diluted pure liquid standards in a Tedlar 
bag. Alternatively, in this work, methyl chavicol was calibrated in the Berkeley GC-MS by manually injecting liquid standards (Sigma-Aldrich) diluted in cyclohexane (SigmaAldrich) into a $100-200 \mathrm{~mL} \mathrm{~min}^{-1}$ stream of nitrogen gas, where the injector port was heated to $100^{\circ} \mathrm{C}$. This standard flow was then subsampled and collected through the same tubing and at the same flow rate as an ambient sample. To ensure no liquid standard condensed in the sampling lines, subsequent blank nitrogen samples were also collected through the calibration pathway. The direct liquid injection technique was reproducible to within $10 \%$ of the gas phase technique when the Tedlar bag was placed in a $40^{\circ} \mathrm{C}$ oven and the standard gas was sampled through Silcosteel tubing heated to $50^{\circ} \mathrm{C}$. The Berkeley GC-MS system was calibrated at least once per day. Measurement uncertainty for methyl chavicol and monoterpenes were $27 \%$ and $18 \%$, respectively.

Berkeley GC-MS measurements were made at two different inlet heights during two distinct sampling periods. One inlet was located $1.5 \mathrm{~m}$ above the forest floor, below the main trees of the canopy but near the juvenile saplings, from 19 August through the morning of 12 September (day of year 231-255). The other inlet was located $9.3 \mathrm{~m}$ above the forest floor, which corresponds to $\sim 2 \mathrm{~m}$ above the mean forest canopy height, from the afternoon of 12 September through 8 October (day of year 255-281). The sampling timeline is outlined in Fig. 2.

\subsubsection{NOAA GC-MS}

Volatile $\mathrm{C}_{2}-\mathrm{C}_{10}$ organic compounds, in particular 2-methyl3-buten-2-ol (MBO) and isoprene, were quantified using a gas chromatograph with mass spectrometer detector (NOAA GC-MS). The sample acquisition procedure is described in detail by Goldan et al. (2004), but more recent modifications to the analysis system will be briefly described here. The inlet was located at $9.3 \mathrm{~m}$ above the canopy floor for three days (24-27 September, day of year 267-270) (Fig. 2) and consisted of $12 \mathrm{~m}$ of $6.35 \mathrm{~mm}$ outer diameter PFA tubing through which approximately $8 \mathrm{~L} \mathrm{~min}^{-1}$ of air was drawn. Care was taken to prevent permeation of VOCs into the sample stream from the mobile laboratory housing the GC-MS. Once the sample inlet tubing entered the laboratory, it was contained inside a $12.7 \mathrm{~mm}$ outer diameter PFA line. The bulk sample flow (>95\%) was then exhausted through the larger diameter coaxial line so that the sample flow itself acted as a counterflowing sheath gas.

The 2-channel custom built system consisted of parallel systems for sample acquisition and separation for subsequent analysis by a single mass spectrometer (formally a GCFID/MS system). Two 5 min samples were acquired concurrently every $30 \mathrm{~min}$ at a rate of $70 \mathrm{~mL} \mathrm{~min}^{-1}$ then analyzed serially. Light alkanes and alkenes $\left(\mathrm{C}_{2}-\mathrm{C}_{5}\right)$ were separated on a $\mathrm{KCl}$ washed Alumina column and analyzed first. Isoprene and $\mathrm{MBO}$, along with the heavier species $\left(\mathrm{C}_{2}-\mathrm{C}_{10}\right)$, were cryofocused and then separated using a metal MXT-
624 column (Restek) with a temperature program ramping from $38^{\circ} \mathrm{C}$ to $127^{\circ} \mathrm{C}$ at $8.1^{\circ} \mathrm{C} \mathrm{min}^{-1}$ and a helium carrier flow of $2 \mathrm{~mL} \mathrm{~min}^{-1}$. The two columns were plumbed into a 4-port valve (Valco) which was then connected to the linear quadrupole mass spectrometer (Agilent 5973).

\subsubsection{PTR-MS}

Volatile organic compounds were also quantified by proton transfer reaction mass spectrometry (PTR-MS), which has been described elsewhere in detail (Lindinger et al., 1998; de Gouw and Warneke, 2007). Five inlets were used to sample vertical gradients within (1.5 m, $6.0 \mathrm{~m}$ above the forest floor) and above $(9.3 \mathrm{~m}, 14.3 \mathrm{~m}, 17.7 \mathrm{~m}$ above the ground) the forest canopy where ambient air from each height was sampled using $6.35 \mathrm{~mm}$ outer diameter PFA tubing. The set-up was similar to that described by Holzinger et al. (2005). Ambient air was drawn down from the tower at $20 \mathrm{~L} \mathrm{~min}^{-1}$ continuously from all levels simultaneously and sub-sampled directly into the instrument at $400 \mathrm{~mL} \mathrm{~min}^{-1}$. Each hour-long sample cycle consisted of a 6-minute sampling period at each level. Twelve individual ions, including the primary $\mathrm{m} / \mathrm{z}$ signal for methyl chavicol, were measured with a variable dwell time that increased at higher $\mathrm{m} / \mathrm{z}$ ratios to obtain reasonable signal to noise ratios across the set. Methyl chavicol was detected at $m / z$ 149, and although the PTR-MS likely detected other compounds at $m / z, 149$, methyl chavicol is assumed to dominate the signal. The PIT-MS instrument described below was used during branch enclosure measurements to verify this assumption.

Methyl chavicol was quantified by correlating the PTRMS response detected at $\mathrm{m} / z, 149$ to the Berkeley GC-MS quantification of methyl chavicol using an authentic standard when the two measurements were co-located at $9.3 \mathrm{~m}$. The slope of correlation had a $19 \%$ relative standard error. MBO was quantified by correlating the sum of $\mathrm{m} / \mathrm{z}, 87$ and $\mathrm{m} / \mathrm{z}, 69$ to the NOAA GC-MS quantification of MBO using an authentic standard when the two instruments were co-located at $9.3 \mathrm{~m}$. The slope of correlation had an $8 \%$ relative standard error. Since isoprene is also detected at $\mathrm{m} / \mathrm{z} 69$, MBO was isolated from the isoprene interference after determining the ratio of MBO to isoprene present using the NOAA GCMS measurements. MBO can be separated this way because the isoprene mixing ratio diurnal pattern is very predictable. The only significant isoprene influence at Blodgett Forest is regularly transported to the site in the afternoon from downwind sources (e.g. Dreyfus et al., 2002).

\subsubsection{PIT-MS}

Proton transfer ion trap mass spectrometry (PIT-MS) uses the same proton transfer reactions employed in PTR-MS to ionize VOCs, but subsequent ion analysis occurs with an ion trap mass spectrometer (Warneke et al., 2005a, b). In addition to measuring VOCs with high time resolution, the PIT-MS 


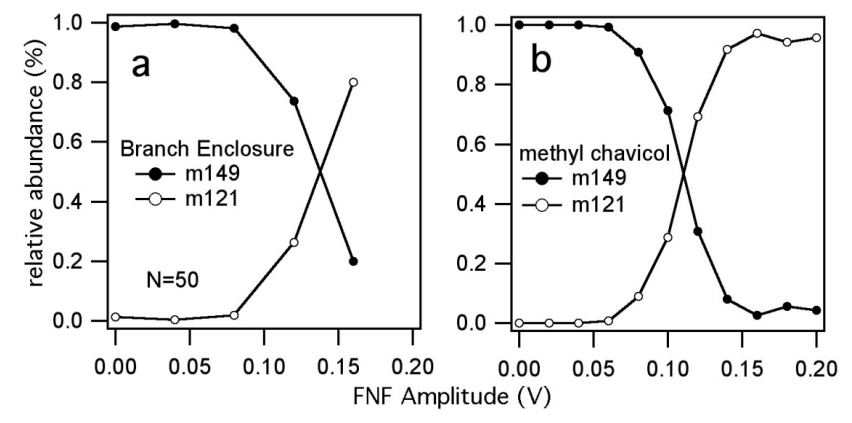

Fig. 3. Proton transfer ion trap mass spectrometer (PIT-MS) collision-induced dissociation (CID) taken (a) during the enclosure of ponderosa pine branch \#1 in July 2005 (as described by BouvierBrown et al., 2009) and (b) on a laboratory standard of methyl chavicol. Relative abundances of parent and fragment ions are shown versus the voltage amplitude of the filtered noise field (FNF) that is used to fragment the parent ions.

can provide additional chemical detail by selectively trapping ions of interest and performing collision-induced dissociation (CID) on these masses before measuring the fragment ions. During the branch enclosure measurements described by Bouvier-Brown et al. (2009), the PIT-MS alternated between full mass scans and CID.

PIT-MS measurements of ponderosa pine branch \#1 in July showed a 30:1 ratio for the signal at $\mathrm{m} / \mathrm{z} 149$ versus the signal at $m / z 205$ (usually attributed to sesquiterpenes) with both ions reaching peak concentrations just after noon PST. Many sesquiterpenes fragment onto $\mathrm{m} / \mathrm{z} 149$ under typical PTR-MS operating conditions, but the concentration differences make interferences from fragments of sesquiterpenes on $m / z 149$ very unlikely. CID spectra of the $m / z 149$ parent ion taken during the branch enclosure measurement reveal a unique fragment ion at $\mathrm{m} / \mathrm{z} 121$ (Fig. 3). Subsequent laboratory experiments with a liquid standard (Aldrich) droplet volatilized in air show that methyl chavicol also produces a fragment at $\mathrm{m} / \mathrm{z} 121$ with a similar relative abundance. Slight differences in filtered noise field (FNF) voltages between the field and laboratory measurements are expected because fragmentation is highly dependent on PIT-MS operational parameters. These data show that the signal on $\mathrm{m} / \mathrm{z}$ 149 in ponderosa pine branch enclosures can very likely be attributed to methyl chavicol without significant inference.

\subsubsection{TAG}

Organic constituents in particulate matter were separated and measured using a Thermal Desorption Aerosol GC-MS (TAG) instrument (custom built from Agilent GC6890/MS5973), which has been described in detail elsewhere (Williams et al., 2006; Kreisberg et al., 2009). Briefly, ambient aerosol samples $\left(\mathrm{PM}_{2.5}\right)$ are collected by humidification and inertial impaction. Following collection, the contents were thermally desorbed into helium carrier gas and transferred onto the head of a gas chromatographic column prior to separation $(30 \mathrm{~m}, 0.25 \mathrm{~mm}, 0.25 \mu \mathrm{m}$ film Rxi-5ms column; Restek Corporation) and detection by mass spectrometry. Samples $\left(0.75 \mathrm{~m}^{3}\right.$ volume $)$ were collected for 1.5 of every $2 \mathrm{~h}$ at a sampling rate of $9 \mathrm{~L} \mathrm{~min}^{-1}$ through $9.52 \mathrm{~mm}$ outer diameter insulated stainless steel tubing from an inlet located $9.3 \mathrm{~m}$ above the ground. The TAG methyl chavicol data are normalized to the maximum response observed during the study.

\subsubsection{SPME fibers}

Solid Phase MicroExtraction (SPME) fibers were periodically used for qualitative analysis of ambient air during BEARPEX. Field portable $65 \mu \mathrm{m}$ polydimethylsiloxanedivinylbenzene (PDMS/DVB) Stableflex fibers (Supelco, Bellefonte, PA) collected analytes in air samples pulled over their surfaces at $\sim 4 \mathrm{~L} \mathrm{~min}^{-1}$ for $4-24 \mathrm{~h}$ and were analyzed using a gas chromatograph with ion trap mass spectrometer as described by Bouvier-Brown et al. (2007). SPME fibers were co-located with both Berkeley GC-MS inlets at 1.5 and $9.3 \mathrm{~m}$ above the forest floor.

\section{Results and discussion}

To characterize methyl chavicol abundance, emission, and oxidation products, this section is broken into four parts: methyl chavicol mixing ratios, methyl chavicol emissions, atmospheric implications, and oxidation products. In 3.1, ambient mixing ratios are used to evaluate the measurement agreement among the three analytical instruments that detected methyl chavicol and show methyl chavicol's variability relative to total terpene mass. In 3.2, methyl chavicol's emission dependence on light and temperature is revealed through comparison to MBO and the monoterpene $\alpha$-pinene. The correlation between methyl chavicol and MBO is then used to estimate methyl chavicol basal emission rates. An estimation of methyl chavicol reaction rates and its atmospheric lifetime as well as observations of the proposed oxidation products are discussed in Sects. 3.3 and 3.4, respectively.

\subsection{Methyl chavicol mixing ratios}

Methyl chavicol was simultaneously measured by the Berkeley GC-MS and PTR-MS, and at the same time it was also detected in the aerosol phase by the TAG instrument. Ambient measurements from the three instruments consistently show a methyl chavicol diurnal profile with mixing ratio maxima in the morning and late evening (Fig. 4). The slight differences in each instrument's profile reflect the different sampling times and inlet types (see Sect. 2.2). The maxima occur at times when the light and temperature are high enough to induce emissions from the trees into a shallow boundary 


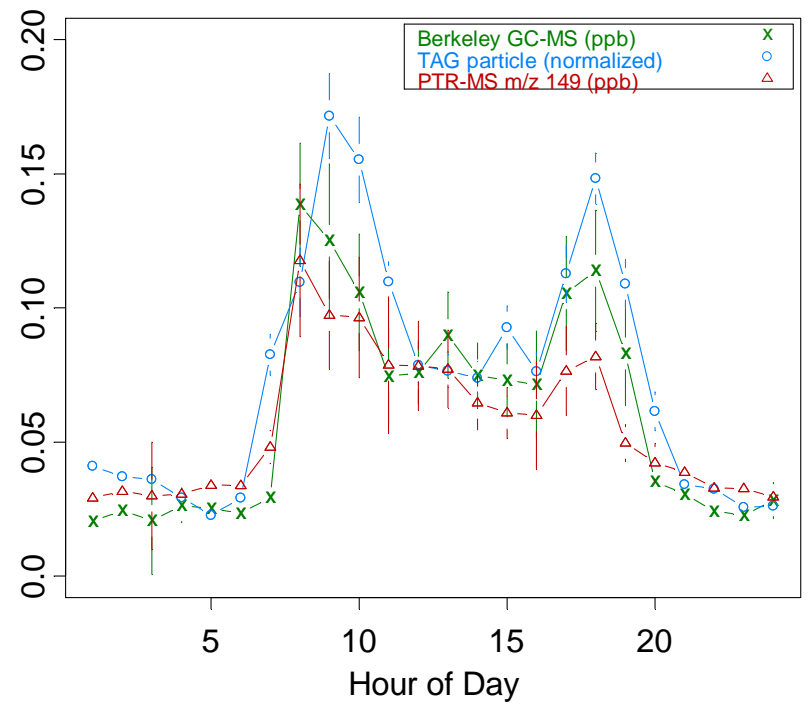

Fig. 4. Diurnal variation of methyl chavicol at Blodgett Forest measured using three different in-situ instruments (mean \pm standard error): the Berkeley gas chromatograph with mass spectrometer detector (Berkeley GC-MS, green $\times$ ), thermal desorption aerosol GCMS (TAG, blue o), and proton-transfer mass spectrometer (PTRMS, red $\Delta$ ) during BEARPEX. All three instruments capture the same diurnal profile at $9.3 \mathrm{~m}$ above the ground. All data are from 12 September-8 October (day of year 255-281).

layer with low oxidant mixing ratios leading to an accumulation of emissions. The mid-afternoon minima are characteristic of vertical mixing into a deeper boundary layer and chemical destruction with both effects overwhelming the increased daytime emissions at higher temperature and solar radiation. Without the influence of vertical mixing and oxidation in the canopy, methyl chavicol mixing ratios would peak in mid-afternoon as observed during branch enclosure experiments (Bouvier-Brown et al., 2009).

The ratio of methyl chavicol to total terpene (sum of the total monoterpenes, sesquiterpenes and oxygenated terpenes) mass is highly variable. During the warm period (20 August12 September, day of year 232-255), methyl chavicol mixing ratios averaged $15 \%$ of the total terpene mass measured at $1.5 \mathrm{~m}$ above the forest floor. During the cooler period (12 September-8 October, day of year 255-281), methyl chavicol mixing ratios averaged $36 \%$ of the total terpene mass just above the canopy at $9.3 \mathrm{~m}$ above the ground. These relative mixing ratios are both within the $9-117 \%$ range measured in ponderosa pine branch enclosures (Bouvier-Brown et al., 2009).

\subsection{Methyl chavicol emissions}

Although monoterpenes and methyl chavicol are all 10carbon BVOCs emitted from this ecosystem, our results show different physical and environmental factors drive their emissions. For example, in this drought-stressed ecosys- tem, enhanced monoterpene emissions occur immediately following wetting by rain. Methyl chavicol emissions, following more closely the emissions of 2-methyl-3-buten-2-ol (MBO), do not increase until a few days after the rain when the temperature begins to increase and full light is available (Fig. 5). The correlation between ambient methyl chavicol and $\alpha$-pinene, an abundant monoterpene, mixing ratios is poor $\left(R^{2}=0.1, n=186\right)$ during this cool period.

During BEARPEX, ambient MBO and monoterpene mixing ratios were largest in the lower canopy and MBO showed the same diurnal pattern throughout the canopy, as seen by Holzinger et al. (2005). During the cool period (12 September-8 October, day of year 255-281), an average diurnal profile of methyl chavicol mixing ratios at each of the five gradient levels measured by the PTR-MS also show the largest mixing ratios low in the canopy (Fig. 6). This clearly indicates that methyl chavicol emissions are local and biogenic in origin, similar to MBO.

At $9.3 \mathrm{~m}$ above the ground during three cool days (2427 September, day of year 267-270) following a large rain event, the average ambient diurnal profiles of methyl chavicol and MBO are strikingly similar, but differ from that of $\alpha$-pinene (Fig. 7). Characteristic of temperature and lightdriven emissions, methyl chavicol and MBO mixing ratios are relatively constant during the hours of full sunlight and significantly larger during the day than at night. On the other hand, for monoterpenes, such as $\alpha$-pinene, mixing ratios are largest at night when vertical mixing is weak and there are continuous temperature-driven emissions from storage pools in plant resins.

During the warm measurement period (20 August-12 September, day of year 232-255) at $1.5 \mathrm{~m}$ above the forest floor, the average diurnal profiles of methyl chavicol and MBO measured by PTR-MS were similar, particularly with respect to the morning and evening peaks (Fig. 8). One important distinction between the profiles is the presence of methyl chavicol at night (Fig. 8). The evidence of nighttime emission is corroborated by the PTR-MS gradient data from the cool period (Fig. 6). Conversely, MBO mixing ratios are very low at night and do not show a vertical gradient (Holzinger et al., 2005). The presence of nighttime methyl chavicol mixing ratios and a vertical gradient indicates a likely temperature-dependent emission mechanism from storage pools similar to the monoterpene emission mechanism at this site. Contrary to monoterpenes, this temperature-dependent emission mechanism is less significant to methyl chavicol's overall emission. Methyl chavicol mixing ratios are 1.8 times larger at night than during the day, whereas monoterpene mixing ratios average 3.5 times more at night at $1.5 \mathrm{~m}$ above the ground during the warm period. Methyl chavicol may have a hybrid emission mechanism where emission occurs both from storage pools and directly after production. However, the daytime emission dominantly occurs directly after production by a temperature and light-driven emission mechanism, similar to that of MBO. 

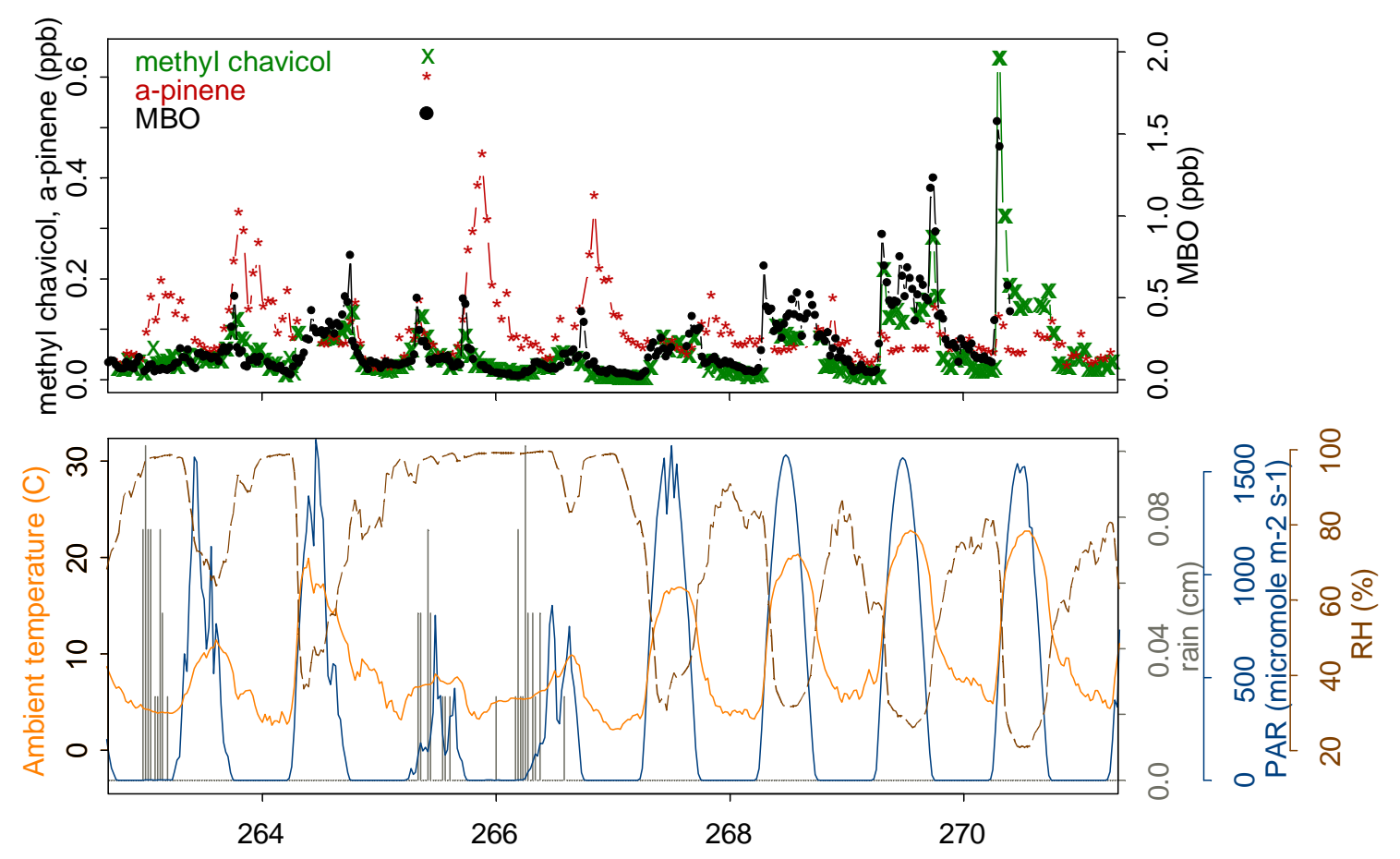

Day of Year 2007

Fig. 5. An example timeline of methyl chavicol (green $\times$ ) and $\alpha$-pinene (red $\star$ ) mixing ratios measured by the Berkeley GC-MS, and 2methyl-3-buten-2-ol (MBO •) mixing ratios measured by the NOAA GC-MS along with temperature (orange -), light (PAR, blue -), relative humidity (RH, brown --) and rainfall (solid grey bars).

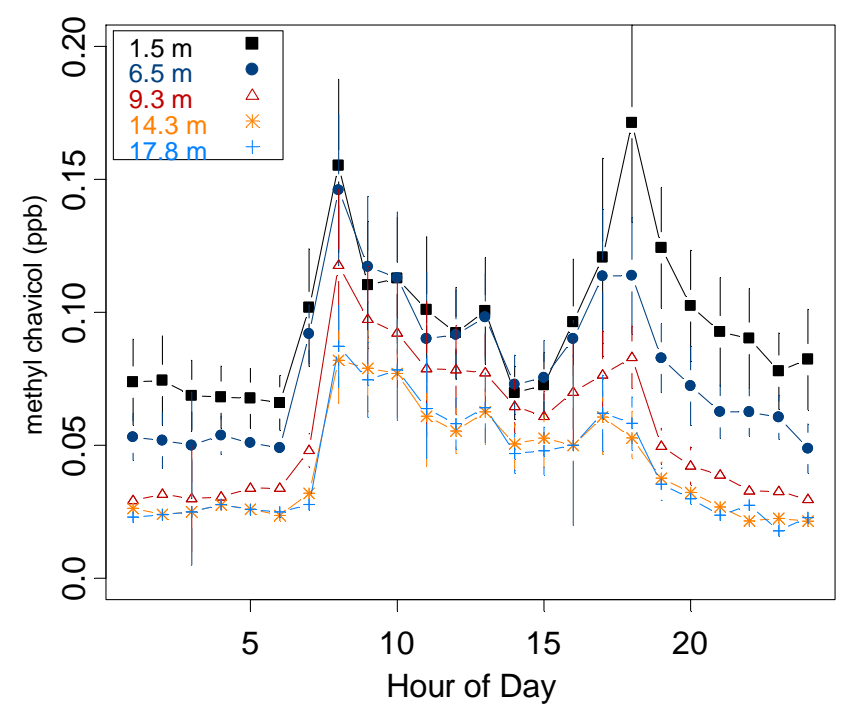

Fig. 6. Average diurnal profiles of methyl chavicol mixing ratios taken at each level of the vertical gradient measured by PTR-MS from 12 September-8 October, day of year 255-281 (mean \pm standard error).

\subsubsection{Estimating methyl chavicol emission rates}

Since methyl chavicol's diurnal profile and atmospheric lifetime (discussed in Sect. 3.3.) are very similar to that of MBO, we can estimate the ecosystem emission of methyl chavicol by scaling the known emission rate for MBO to the slope of their correlation. When the NOAA GC-MS and the Berkeley GC-MS measurements were co-located (Fig. 2), a linear regression of methyl chavicol vs. MBO daytime mixing ratios yields a slope of $0.34 \pm 0.03$ (mean \pm standard deviation) and a correlation coefficient of 0.82 (Fig. 9). Assuming that these compounds have similar sources and sinks, their correlation during this cool period indicates that methyl chavicol emissions are, on average, $34 \%$ of $\mathrm{MBO}$ emissions. In terms of the amount of photosynthetic carbon lost to the atmosphere during the three days, methyl chavicol emissions account for $68 \%$ of the carbon mass of MBO emissions because methyl chavicol has twice the amount of carbon per molecule. Given a MBO basal emission range of $\sim 5-15 \mu \mathrm{gCg}^{-1} \mathrm{~h}^{-1}$, depending on needle age, from ponderosa pine trees at Blodgett Forest during a similar cool fall period (day of year 256287) (Schade et al., 2000; Gray et al., 2005), an estimated basal emission rate for methyl chavicol is $3-10 \mu \mathrm{gCg}^{-1} \mathrm{~h}^{-1}$. Additional analysis of the branch enclosure measurements from summer 2005 conducted in a warm and dry environment described by Bouvier-Brown et al. (2009) reveals that 


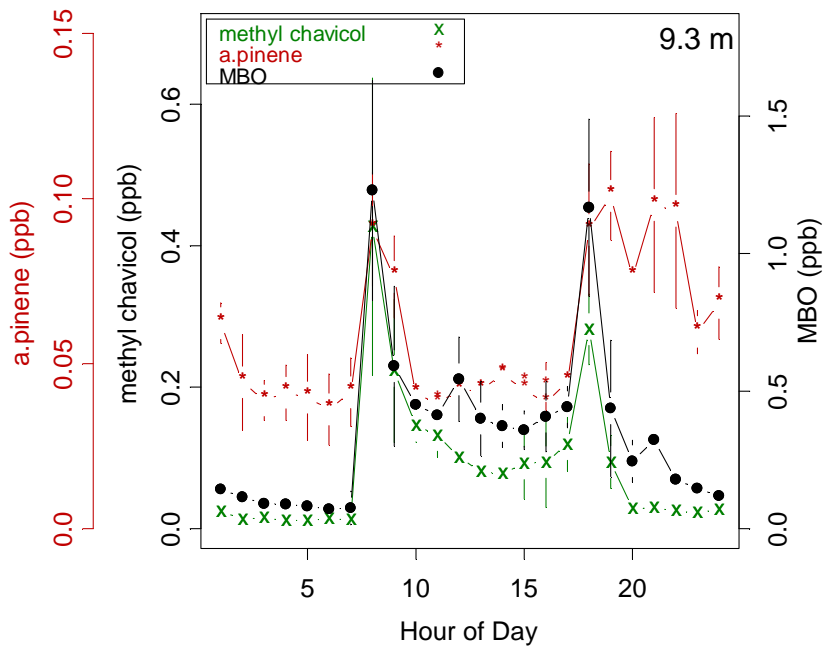

Fig. 7. Average diurnal profiles of methyl chavicol (green $\times$ ), MBO (black $\bullet$ ), and $\alpha$-pinene (red $\star$ ) (mean \pm standard error). Measurements were made at $9.3 \mathrm{~m}$ from 24-27 September (day of year 267270), and MBO was measured by NOAA GC-MS

this relative emission rate varies with season because MBO emissions have a stronger temperature dependence. A similar linear regression of methyl chavicol vs. MBO yields a slope within the range of $0.02-0.12$, depending on the branch $\left(R^{2}=0.81-0.96, n=164-814\right)$. As a result, methyl chavicol emissions account for 4-24\% of the carbon mass emitted by $\mathrm{MBO}$ in warm and dry conditions. Using the maximum average MBO basal emission rate from ponderosa pine trees at Blodgett Forest of $18 \mu \mathrm{gCg}^{-1} \mathrm{~h}^{-1}$ (Schade et al., 2000), an estimated methyl chavicol basal emission rate ranges from $0.7-4.3 \mu \mathrm{gCg}^{-1} \mathrm{~h}^{-1}$ in warm and dry conditions. The estimated ecosystem flux of $0.491 \mu \mathrm{gCg}^{-1} \mathrm{~h}^{-1}$ (which is equivalent to $1.37 \mu \mathrm{mol} \mathrm{m}^{-2} \mathrm{~h}^{-1}$ ) reported by Bouvier-Brown et al. (2009) under similar warm and dry conditions is likely underestimated because controlled experiments were not conducted to assess the light dependence parameters of the emissions.

\subsection{Atmospheric implications}

No reaction rates for methyl chavicol have been reported in the literature, so we used data collected during ozonolysis and photooxidation chamber studies described by Lee et al. (2006a, b) to estimate reaction rate coefficients. We correlated the loss rate of methyl chavicol with the loss rate of other compounds tested that have reaction rate coefficients in the literature. These estimates $\left(k_{\mathrm{OH}}\right.$ $=5.7 \times 10^{-11} \mathrm{~cm}^{3} \mathrm{molec}^{-1} \mathrm{~s}^{-1}$ and $k_{\mathrm{O} 3}=1.4 \times$ $10^{-17} \mathrm{~cm}^{3} \mathrm{molec}^{-1} \mathrm{~s}^{-1}$ ) agree with rate coefficients calculated using the Environmental Protection Agency's Estimation Program Interface Suite $\left(k_{\mathrm{OH}}=5.4 \times 10^{-11} \mathrm{~cm}^{3}\right.$ molec $^{-1} \mathrm{~s}^{-1}, k_{\mathrm{O} 3}=1.2 \times 10^{-17} \mathrm{~cm}^{3} \mathrm{molec}^{-1} \mathrm{~s}^{-1}$ ) based solely on chemical structure (US EPA AOPWIN, 2000).

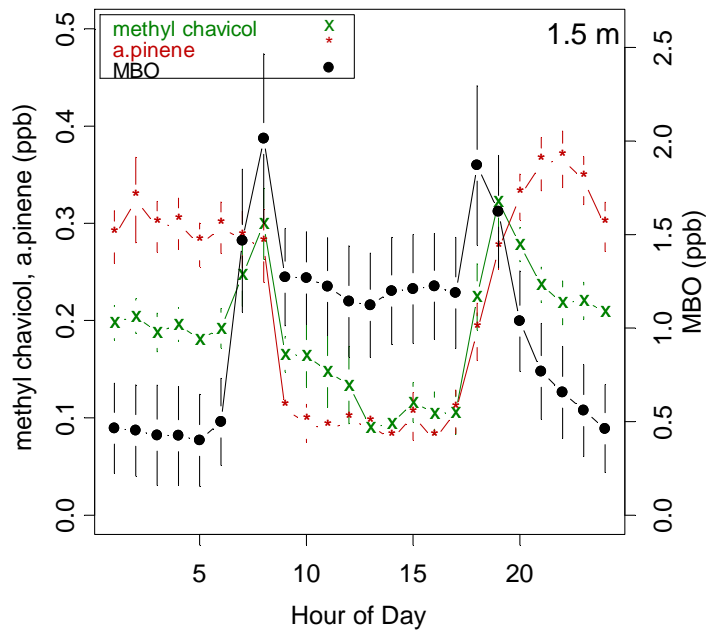

Fig. 8. Average diurnal profiles of methyl chavicol (green $\times$ ), MBO (black $\bullet$ ), and $\alpha$-pinene (red $\star$ ) (mean \pm standard error). Measurements were made at $1.5 \mathrm{~m}$ above the ground from 20 August-12 September (day of year 232-255), and MBO was measured by PTRMS.

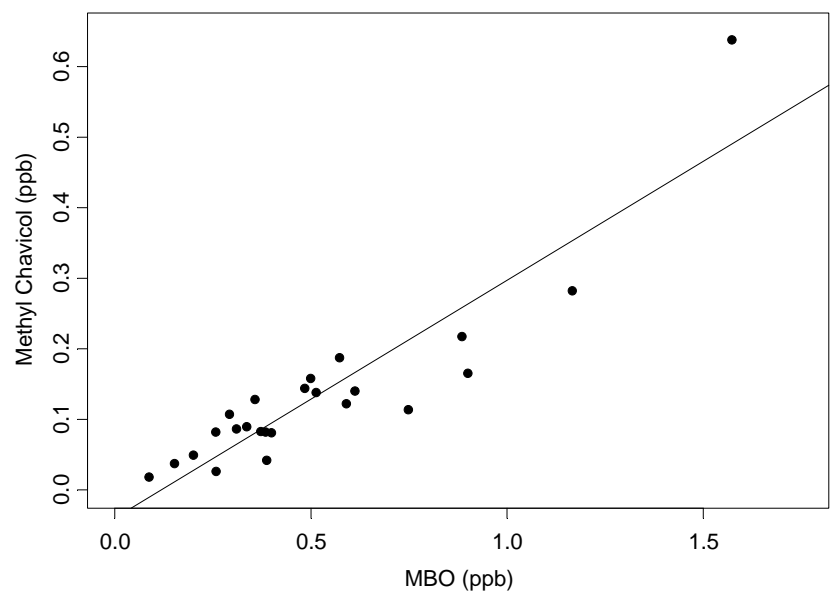

Fig. 9. Methyl chavicol measured by the Berkeley GC-MS and MBO measured by the NOAA GC-MS were tightly correlated when daytime measurements were co-located at $9.3 \mathrm{~m}$ above the forest floor (24-27 September, day of year 267-270). A slope of $0.34 \pm 0.03$ ( $R^{2}$ of 0.82 , intercept of $-0.04, n=24$ ) indicates that the methyl chavicol emissions average $34 \%$ of MBO emissions by molecule (or $68 \%$ by mass carbon) during this period, assuming their atmospheric loss rates are similar.

These estimated rate coefficients are very similar to that of $\mathrm{MBO}\left(k_{\mathrm{OH}}=5.8 \times 10^{-11} \mathrm{~cm}^{3} \mathrm{molec}^{-1} \mathrm{~s}^{-1}, k_{\mathrm{O} 3}=9.7 \times\right.$ $10^{-17} \mathrm{~cm}^{3} \mathrm{molec}^{-1} \mathrm{~s}^{-1}$; Atkinson and Arey, 2003), thus supporting our method of estimating methyl chavicol's emission rate from that of MBO.

Significant amounts of methyl chavicol escape from the Blodgett Forest canopy and are transported downwind. Using an average $\mathrm{OH}$ mixing ratio of $5.4 \times 10^{6} \mathrm{molec} \mathrm{cm}^{-3}$ 


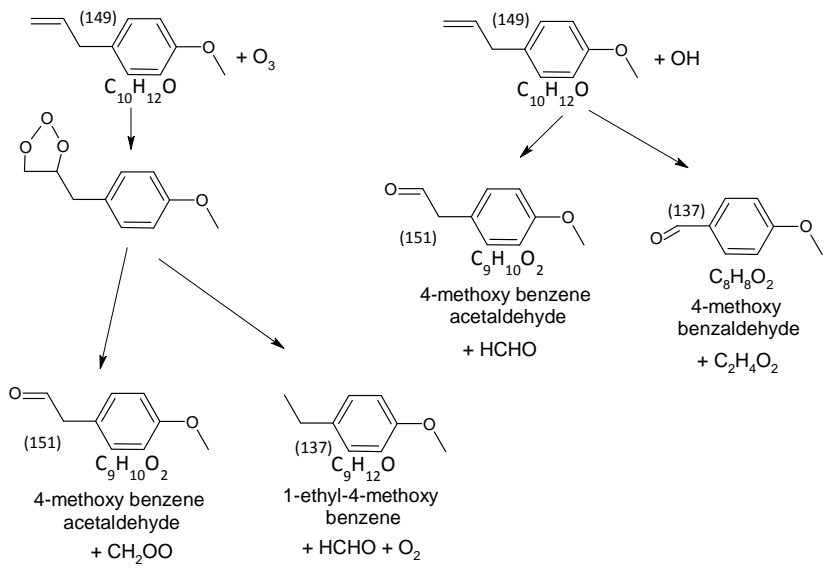

Fig. 10. Schematic of methyl chavicol oxidation products from reanalysis of laboratory methyl chavicol oxidation experiments by Lee et al. (2006a, b). Mass/charge $(\mathrm{m} / \mathrm{z}$ ) ratios detected by PTR-MS are indicated in parentheses.

(0.25 ppt) observed at $9.4 \mathrm{~m}$ between 09:00-16:00 PST at BEARPEX (W. Brune and J. Mao, personal communication, 2008), an ozone mixing ratio of $1.18 \times 10^{12}$ molec cm$^{-3}$ (55 ppb), and the estimated reaction rates of methyl chavicol, the lifetimes are $\sim 55 \mathrm{~min}$ and $\sim 1100 \mathrm{~min}$ with $\mathrm{OH}$ and ozone, respectively. These lifetimes are significantly longer than the estimated 1-10 min canopy sweep time (Kurpius and Goldstein, 2003; Holzinger et al., 2005; Farmer and Cohen, 2008), indicating that essentially all of the emitted methyl chavicol escapes from the forest canopy and contributes to regional photochemistry through reaction with $\mathrm{OH}$. Looking at all the VOCs at Blodgett Forest, methyl chavicol contributes $1-3 \%$ to the overall $\mathrm{OH}$ reactivity just above the forest canopy (J. Mao, personal communication, 2008).

\subsection{Oxidation products}

Based on products reported from laboratory oxidation experiments presented by Lee et al. (2006a, b), we propose a schematic of methyl chavicol oxidation (Fig. 10) and identify the major products detected at PTR-MS $\mathrm{m} / \mathrm{z}$ 137 and 151. The photooxidation product observed at $\mathrm{m} / z$ 137, 4-methoxybenzaldehyde (CAS\# 123-11-5) was detected at Blodgett Forest during BEARPEX by TAG and SPME fiber analysis of ambient air. TAG detected 4methoxybenzaldehyde in the aerosol phase, but the phase of compounds collected by SPME fibers in ambient air is unclear. SPME fibers, while usually employed for gas phase analysis are able to detect particulate matter (Koziel et al., 2001). Spada et al. (2008) quantified 4methoxybenzaldehyde in Roseville, CA, a site that receives air from the Sierra Nevada Mountains during nighttime downslope flow, and highlighted its biogenic origin with increased summer concentrations.

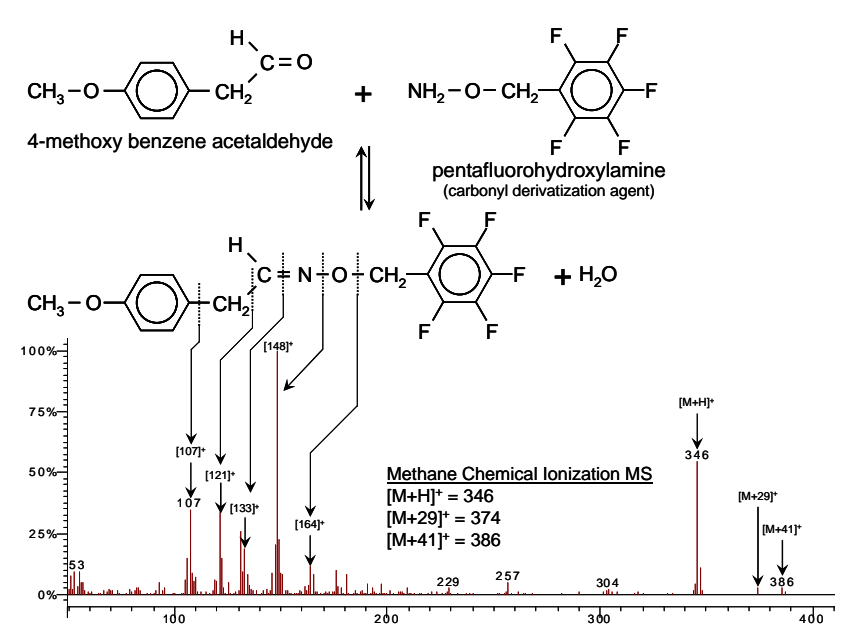

Fig. 11. Schematic of 4-methoxy benzene acetaldehyde derivatization and chemical ionization mass spectrometric detection from the reanalysis of filter samples collected during the experiment at Blodgett Forest described by Cahill et al. (2006).

Lee et al. (2006a, b) observed a product at $\mathrm{m} / \mathrm{z} 151$ via both photooxidation and ozonolysis of methyl chavicol. The proposed oxidation product at PTR-MS $\mathrm{m} / \mathrm{z} 151$ is identified as 4-methoxy benzene acetaldehyde (CAS\# 5703-264) (Fig. 10). Previous observations of $\mathrm{m} / \mathrm{z} 151$ have been made at Blodgett Forest, but this fragment was attributed entirely to pinonaldehyde (Holzinger et al., 2005). The observed gaseous $m / z, 151$ fragment at Blodgett Forest is most likely the combination of at least these two aldehydes. 4Methoxy benzene acetaldehyde has also been tentatively detected in a reanalysis of particulate samples collected by Cahill et al. (2006) (Fig. 11). These results show that 4methoxy benzene acetaldehyde was 1.3-5.5 times higher at night compared to the day, for a 5 day sampling period. This nighttime abundance is within the range of monoterpene oxidation product increases (2-8 times) at night reported by Cahill et al. (2006).

Due to methyl chavicol's atmospheric lifetime, its oxidation products will be produced regionally and affect areas downwind from the emission sources. The observation of 4methoxybenzaldehyde in Roseville demonstrates that methyl chavicol and its oxidation products contribute to regional secondary organic aerosol (SOA) loading.

\section{Conclusions}

Methyl chavicol is abundantly emitted by a ponderosa pine forest and was simultaneously quantified by three independent in-situ analytical methods (Berkeley GC-MS, PTR-MS, and TAG). In ambient air, its abundance equaled $15-36 \%$ of the total gas phase terpene mass within and just above the canopy. Methyl chavicol mixing ratios were highly correlated with MBO suggesting that methyl chavicol daytime 
emissions can be modeled using a light- and temperaturedependent algorithm. Scaling from its correlation with MBO, methyl chavicol's carbon mass accounts for $68 \%$ of the carbon mass emitted as MBO during cool and wet conditions and 4-24\% of the MBO carbon mass emitted during warm and dry conditions. From these relationships, we estimate methyl chavicol basal emission rate from ponderosa pine trees to be $3-10 \mu \mathrm{gCg}^{-1} \mathrm{~h}^{-1}$ during cool and wet conditions and $0.7-4.3 \mu \mathrm{gCg}^{-1} \mathrm{~h}^{-1}$ during warm and dry conditions, depending on needle age and seasonality. These emission parameters should be incorporated in BVOC emission models.

Both methyl chavicol as a primary emission and its oxidation products (4-methoxybenzaldehyde and 4-methyoxy benzene acetaldehyde) contribute to the aerosol loading at Blodgett Forest and throughout the region. Similar to MBO or monoterpenes, such as $\alpha$-pinene, methyl chavicol effectively escapes the forest canopy because its lifetime $(\sim 1 \mathrm{~h})$ is significantly longer than the estimated canopy sweep time (1-10 min). Therefore, methyl chavicol will have an impact on atmospheric chemistry at the regional scale, perhaps similar in scope to that demonstrated for MBO by Steiner et al. (2007), and therefore should be incorporated in atmospheric chemistry models.

A wide variety of plants around the world are known to contain methyl chavicol (Table 1), and therefore it is likely that biogenic emissions of methyl chavicol are common. With the deployment of improved analytical instrumentation targeting less volatile compounds, we predict that methyl chavicol will be found in the ambient air near many other ecosystems, where it will play a role in regional atmospheric chemistry and production of SOA.

Acknowledgements. This material is supported by the National Science Foundation Atmospheric Chemistry Program under grant 0443448. The authors would also like to thank Sierra Pacific Industries for the use of their land, the Blodgett Forest crew for their support, and S. Seybold (USDA Forest Service, Davis, CA) for background information regarding methyl chavicol's use in entomology.

Edited by: J. Williams

\section{References}

Adams, R. P. and Edmunds Jr., G. F.: A re-examination of the volatile leaf oils of Pinus ponderosa Dougl. Ex. P. Lawson using Ion Trap Mass Spectrometry, Flavour Frag. J., 4, 19-23, 1989.

Adams, R. P.: Identification of essential oil components by gas chromatography/mass spectrometry, Allured Publishing Corp., Carol Stream, Illinois, USA, 804 pp., 2007.

Atkinson, R. and Arey, J.: Gas-phase tropospheric chemistry of biogenic volatile organic compounds: A review, Atmos. Environ., 37, S197-S219, 2003.
Baker, B., Guenther, A., Greenberg, J., Goldstein, A., and Fall, R.: Canopy fluxes of 2-methyl-3-buten-2-ol over a ponderosa pine forest by relaxed eddy accumulation: Field data and model comparison, J. Geophys. Res., 104, 26107-26114, 1999.

Barazani, O., Cohen, Y., Fait, A., Diminshtein, S., Dudai, N., Ravid, U., Putievsky, E., and Friedman, J.: Chemotypic differentiation in indigenous populations of Foeniculum vulgare var. vulgare in Israel, Biochem. Syst. Ecol., 30, 721-731, 2002.

Bauer, M. R., Hultman, N. E., Panek, J. A., and Goldstein, A. H.: Ozone deposition to a ponderosa pine plantation in the Sierra Nevada Mountains (CA): A comparison of two different climatic years, J. Geophys. Res., 105, 22123-22136, 2000.

Bouvier-Brown, N. C., Holzinger, R., Palitzsch, K., and Goldstein, A. H.: Quantifying sesquiterpene and oxygenated terpene emissions from live vegetation using solid-phase microextraction fibers, J. Chromatogr. A, 1161, 113-120, 2007.

Bouvier-Brown, N. C., Holzinger, R., Palitzsch, K., and Goldstein, A. H.: Large emissions of sesquiterpenes and methyl chavicol quantified from branch enclosure measurements, Atmos. Environ., 43, 389-401, 2009.

Brophy, J. J. and Boland, D. J.: The leaf essential oil of two chemotypes of Backhousia anisata Vickery, Flavour Frag. J., 6, 187$188,1991$.

Cahill, T. M., Seaman, V. Y., Charles, M. J., Holzinger, R., and Goldstein, A. H.: Secondary organic aerosol formed from oxidation of biogenic volatile organic compounds in the Sierra Nevada Mountains of California, J. Geophys. Res., 111, D16312, doi:10.1029/2006JD007178, 2006.

Chadwick, T. C. and Palkin, S.: Composition of American gum terpentine exclusive of the pinenes, USDA Technical Bulletin No. 749, 16 pp., 1941.

Ciccio, J. F.: A source of almost pure methyl chavicol: volatile oil from the aerial parts of Tagetes lucida (Asteraceae) cultivated in Costa Rica, Rev. Biol. Trop., 54(4), 853-857, 2004.

Cobb Jr., F. W., Zavarin, E., and Bergot, J.: Effect of air pollution on the volatile oil form leaves of Pinus ponderosa, Phytochemistry, 11, 1815-1818, 1972.

de Gouw, J. and Warneke, C.: Measurements of volatile organic compounds in the Earth's atmosphere using Proton-TransferReaction Mass Spectrometry, Mass Spectrom. Rev., 26, 223257, 2007.

De Vincenzi, M., Silano, M., Maialetti, F., and Scazzocchio, B.: Constituents of aromatic plants: II. Estragole, Fitoterapia, 71, 725-729, 2000.

Dreyfus, G. B., Schade, G. W., and Goldstein, A. H.: Observational constraints on the contribution of isoprene oxidation to ozone production on the western slope of the Sierra Nevada, California, J. Geophys. Res., 107(D19), 4365, doi:10.1029/2001JD001490, 2002.

Duke, J. A.: Handbook of medicinal herbs, CRC Press, Boca Raton, 896 pp., 2001.

Farmer, D. K. and Cohen, R. C.: Observations of $\mathrm{HNO}_{3}, \sum \mathrm{AN}$, $\sum \mathrm{PN}$ and $\mathrm{NO}_{2}$ fluxes: evidence for rapid $\mathrm{HO}_{\mathrm{x}}$ chemistry within a pine forest canopy, Atmos. Chem. Phys., 8, 3899-3917, 2008, http://www.atmos-chem-phys.net/8/3899/2008/.

Fleisher, A. and Fleisher, Z.: Study of Dictamnus gymnostylis volatiles and plausible explanation of the "burning bush" phenomenon, J. Essent. Oil Res., 16(1), 1-3, 2004.

Fuentes, J. D., Lerdau, M., Atkinson, R., Baldocchi, D., Botten- 
heim, J. W., Ciccioli, P., Lamb, B., Geron, C., Gu, L., Guenther, A., Sharkey, T. D., and Stockwell, W.: Biogenic hydrocarbons in the atmospheric boundary layer: A review, B. Am. Meteorol. Soc., 81, 1537-1575, 2000.

Goldan, P. D., Kuster, W. C., Fehsenfeld, F. C., and Montzka, S. A.: The observation of a $\mathrm{C}_{5}$ alcohol emission in a North American pine forest, Geophys. Res. Lett., 20(11), 1039-1042, 1993.

Goldan, P. D., Kuster, W. C., Williams, E., Murphy, P. C., Fehsenfeld, F. C., and Meagher, J.: Nonmethane hydrocarbon and oxy hydrocarbon measurements during the $2002 \mathrm{New}$ England Air Quality Study, J. Geophys. Res., 109, D21309, doi:10.1029/2003JD004455, 2004.

Goldstein, A. H., Hultman, N. E., Fracheboud, J. M., Bauer, M. R., Panek, J. A., Xu, M., Qi, Y., Guenther, A. B., and Baugh, W.: Effects of climate variability on the carbon dioxide, water, and sensible heat fluxes above a ponderosa pine plantation in the Sierra Nevada, CA, Agr. Forest Meteorol., 101, 113-129, 2000.

Gray, D. W., Goldstein, A. H., and Lerdau, M. T.: The influence of light environment on photosynthesis and basal methylbutenol emission from Pinus ponderosa, Plant Cell Environ., 28, 14631474, 2005.

Hayes, J. L. and Strom, B. L.: 4-allylanisole as an inhibitor of bark beetle (Coleoptera: Scolytidae) aggregation, J. Econ. Entomol., 87(6), 1586-1594, 1994.

Hayes, J. L., Strom, B. L., Roton, L. M., and Ingram Jr., L. L.: Repellent properties of the host compound 4-allylanisole to the southern pine beetle, J. Chem. Ecol., 20(7), 1595-1615, 1994.

Hazarika, A. K. and Nath, S. C.: Methyl chavicol - The major component of the rhizome oil of Amomum linguiforme benth., J. Essent. Oil Res., 7, 325-326, 1995.

Helmig, D., Ortega, J., Duhl, T., Tanner, D., Guenther, A., Harley, P., Wiedinmyer, C., Milford, J., and Sakulyanontvittaya, T.: Sesquiterpene emissions from pine trees - Identifications, emission rates and flux estimates for the contiguous United States, Environ. Sci. Technol., 41, 1545-1553, 2007.

Himejima, M., Hobson, K. R., Otsuka, T., Wood, D. L., and Kubo, I.: Antimicrobial terpenes from the oleoresin of ponderosa pine tree Pinus ponderosa: A defense mechanism against microbial invasion, J. Chem. Ecol., 18(10), 1809-1818, 1992.

Holzinger, R., Lee, A., Paw, K. T., and Goldstein, U. A. H.: Observations of oxidation products above a forest imply biogenic emissions of very reactive compounds, Atmos. Chem. Phys., 5, 67-75, 2005, http://www.atmos-chem-phys.net/5/67/2005/.

Holzinger, R., Lee, A., McKay, M., and Goldstein, A. H.: Seasonal variability of monoterpene emission factors for a ponderosa pine plantation in California, Atmos. Chem. Phys., 6, 1267-1274, 2006,

http://www.atmos-chem-phys.net/6/1267/2006/.

Joseph, G., Kelsey, R. G., Peck, R. W., and Niwa, C. G.: Response of some scolytids and their predators to ethanol and 4allylanisole in pine forests of central Oregon, J. Chem. Ecol., 27, 697-715, 2001.

Kaya, A., Demirci, B., and Can Bas,er, K. H.: Study of the essential oils from the flowers and fruits of Scandix iberica Bieb. growing in Turkey, J. Essent. Oil Res., 19(2), 155-156, 2007.

Koziel, J. A., Odziemkowski, M., and Pawliszyn, J.: Sampling and analysis of airborne particulate matter and aerosols using inneedle trap and SPME fiber devices, Anal. Chem., 73, 47-54,
2001.

Krauze-Baranowska, M., Mardarowicz, M., Wiwart, M., Poblocka, L., and Dynowska, M.: Antifungal activity of the essential oils from some species of the genus Pinus, Verlag der Zeitschrift fur Naturforschung, 57c, 478-482, 2002.

Kreisberg, N. M., Hering, S. V., Williams, B. J., and Goldstein, A. H.: Quantification of hourly speciated organic compounds in atmospheric aerosols, measured by an in-situ Thermal desorption Aerosol Gas chromatograph (TAG), Aerosol Sci. Tech., 43, 38 $52,2009$.

Kurose, K., Okamura, D., and Yatagai, M.: Composition of the essential oil from the leaves of nine Pinus species and the cones of three of Pinus species, Flavour Frag. J., 22, 10-20, 2007.

Kurpius, M. R. and Goldstein, A. H.: Gas-phase chemistry dominates $\mathrm{O}_{3}$ loss to a forest, implying a source of aerosols and hydroxyl radicals to the atmosphere, Geophys. Res. Lett., 30, 1371, doi:10.1029/2002GL016785, 2003.

Lamanna, M. S. and Goldstein, A. H.: In situ measurements of C2-C10 volatile organic compounds above a Sierra Nevada ponderosa pine plantation, J. Geophys. Res., 104, 21247-21262, 1999.

Lee, A., Schade, G. W., Holzinger, R., and Goldstein, A. H.: A comparison of new measurements of total monoterpene flux with improved measurements of speciated monoterpene flux, Atmos. Chem. Phys., 5, 505-513, 2005,

http://www.atmos-chem-phys.net/5/505/2005/.

Lee, A., Goldstein, A. H., Keywood, M. D., Gao, S., Varutbangkul, V., Bahreini, R., Ng, N. L., Flagan, R. C., and Seinfeld, J. H.: Gas-phase products and secondary aerosol yields from the ozonolysis of ten different terpenes, J. Geophys. Res., 111, D07302, doi:10.1029/2005JD006437, 2006a.

Lee, A., Goldstein, A. H., Kroll, J. H., Ng, N. L., Varutbangkul, V., Flagan, R. C., and Seinfeld, J. H.: Gas-phase products and secondary aerosol yields from the photoxidation of 16 different terpenes, J. Geophys. Res., 111, D17305, doi:10.1029/2006JD007050, 2006b.

Lerdau, M., Guenther, A., and Monson, R.: Plant production and emission of volatile organic compounds, Bioscience, 47(6), 373383, 1997.

Leung, A. Y. and Foster, S.: Encyclopedia of common natural ingredients, John Wiley \& Sons, New York, NY, 1996.

Lindinger, W., Hansel, A., and Jordan, A.: On-line monitoring of volatile organic compounds at pptv levels by means of protontransfer-reaction mass spectrometry (PTR-MS) - Medical applications, food control, and environmental research, Int. J. Mass Spectrom., 173(3), 191-241, 1998.

Mazza, G. and Kiehn, F. A.: Essential oil of Agastache foeniculum, a potential source of methyl chavicol, J. Essent. Oil Res., 4, 295299, 1992.

Merle, H., Ferriol, M., Boira, H., and Blaizquez, A.: Composition of the essential oil of Dictamnus hispanicus from Spain, J. Essent. Oil Res., 18(5), 483-485, 2006.

Millet, D. B., Donahue, N. M., Pandis, S. N., Polidori, A., Stanier, C. O., Turpin, B. J., and Goldstein, A. H.: Atmospheric volatile organic compound measurements during the Pittsburgh Air Quality Study: Results, interpretation, and quantification of primary and secondary contributions, J. Geophys. Res., 110, D07S07, doi:10.1029/2004JD004601, 2005.

Mirov, N. T.: Composition of gum terpentines of pines, USDA For- 
est Service, Technical Bulletin No. 1239, 158 pp., 1961.

Mirov, N. T.: The terpenes (in relation to the biology of genus $\mathrm{Pi}$ nus), Annu. Rev. Biochem., 17, 521-540, 1948.

Nebeker, T. E., Schmitz, R. F., Tisdale, R. A., and Hobson, K. R.: Chemical and nutritional status of dwarf mistletoe, Armillaria root rot, and Comandra blister rust infected trees which may influence tree susceptibility to bark beetle attack, Can. J. Botany, 73, 360-369, 1995.

Ondarza, M. and Sanchez, A.: Steam distillation and supercritical fluid extraction of some Mexican spices, Chromatographia, 30, 16-23, 1990.

Papadopoulou, P., Couladis, M., and Tzakou, O.: Essential oil composition of two Greek Echinops species: E. graecus Miller and E. ritro L., J. Essent. Oil Res., 18(3), 242-243, 2006.

Pino, J. A., Marbot, R., and Marti, M. P.: Chemical composition of the essential oil of Helenium amarum (Raf.) H. Rock from Cuba, J. Essent. Oil Res., 18(4), 438-439, 2006a.

Pino, J. A., Marbot, R., and Marti, M. P.: Leaf oil of persea americana Mill. var. drymifolia cv. Duke grown in Cuba, J. Essent. Oil Res., 18(4), 440-442, 2006b.

Pollmann, J., Ortega, J., and Helmig, D.: Analysis of atmospheric sesquiterpenes: Sampling losses and mitigation of ozone interferences, Environ. Sci. Technol., 39, 9620-9629, 2005.

Ramanoelina, P. A. R., Rasoarahona, J. R. E., and Gaydou, E. M.: Chemical composition of Ravensara aromatica Sonn. leaf essential oils from Madagascar, J. Essent. Oil Res., 18(2), 215-217, 2006.

Rezzi, S., Bighelli, A., Mouillot, D., and Casanova, J.: Compostion and chemical variability of the needle essential oil of Pinus nigra subsp. laricio from corsica, Flavour Frag. J., 16, 379-383, 2001.

Sajjadi, S. E.: Analysis of the essential oils of two cultivated basil (Ocimum basilicum L.) from Iran, DARU, 14, 128-130, 2006.

Sakulyanontvittaya, T., Duhl, T., Wiedinmyer, C., Helmig, D., Matsunaga, S., Potosnak, M., Milford, J., and Guenther, A.: Monoterpene and sesquiterpene emission estimates for the United States, Environ. Sci. Technol., 42(5), 1623-1629, 2008.

Salom, S. M. and Hobson, K.: Application of semiochemicals for management of bark beetle infestations - proceedings of an informal conference, Annual meeting of the Entomological Society of America 12-16 December 1993, Indianapolis, IN, USA, Gen. Tech. Rep. INT-GTR-318, Ogden, UT: USDA Forest Service, 1995.

Sangwan, N. S., Farooqui, A. H. A., Shabih, F., and Sangwan, R. S.: Regulation of essential oil production in plants, Plant Growth Regul., 34, 3-21, 2001.

Schade, G. W., Goldstein, A. H., and Lamanna, M. S.: Are monoterpene emissions influenced by humidity?, Geophys. Res. Lett., 26, 2187-2190, 1999.

Schade, G. W., Goldstein, A. H., Gray, D. W., and Lerdau, M. T.: Canopy and leaf level 2-methyl-3-buten-2-ol fluxes from a ponderosa pine plantation, Atmos. Environ., 34, 3535-3544, 2000.

Schade, G. W. and Goldstein, A. H.: Fluxes of oxygenated volatile organic compounds from a ponderosa pine plantation, J. Geophys. Res., 106, 3111-3123, 2001.

Schade, G. W. and Goldstein, A. H.: Increase of monoterpene emissions from a pine plantation as a result of mechanical disturbances, Geophys. Res. Lett., 30, 1380, doi:10.1029/2002GL016138, 2003.

Shin, S. and Kang, C.-A.: Antifungal activity of the essential oil of
Agastache rugosa Kuntze and its snynergism with ketoconazole, Lett. Appl. Microbiol., 36, 111-115, 2003.

Simon, J. E., Quinn, J., and Murray, R. G.: Basil: A source of essential oils, in: Advances in new crops, edited by: Janick, J. and Simon, J. E., Timber Press, Portland, OR, 484-489, 1990.

Snyder, M. A. and Bower, N. W.: Resistance to bark beetle attack in Caribbean pine: Potential role of 4-allylanisole, Biotropica, 37(4), 702-705, 2005.

Southwell, I. A., Russell, M. F., Smith, R. L., and Vinnicombe, A.: Ochrosperma lineare, a new source of methyl chavicol, J. Essent. Oil Res., 15(5), 329-330, 2003.

Spada, N., Fujii, E., and Cahill, T. M.: Diurnal cycles of acrolein and other small aldehydes in regions impacted by vehicle emissions, Environ. Sci. Technol., 42(19), 7084-7090, doi:10.1021/es801656e, 2008.

Steiner, A. L., Tonse, S., Cohen, R. C., Goldstein, A. H., and Harley, R. A.: Biogenic 2-methyl-3-buten-2-ol increases regional ozone and HOx sources, Geophys. Res. Lett., 34, L15806, doi:10.1029/2007GL030802, 2007.

Steiner, A. L., Cohen, R. C., Harley, R. A., Tonse, S., Millet, D. B., Schade, G. W., and Goldstein, A. H.: VOC reactivity in central California: comparing an air quality model to ground-based measurements, Atmos. Chem. Phys., 8, 351-368, 2008, http://www.atmos-chem-phys.net/8/351/2008/.

Strom, B. L., Goyer, R. A., Ingram Jr., L. L., Boyd, G. D. L., and Lott, L. H.: Oleoresin: characteristics of progeny of loblolly pines that escaped attack from the southern pine beetle, Forest Ecol. Manag., 158, 168-178, 2002.

Strom, B. L., Clarke, S. R., and Shea, P. J.: Efficacy of 4allylanisole-based products for protecting individual loblolly pines from Dendroctonus frontalis Zimmermann (Coleoptra: Scolytidae), Can. J. Forest Res., 34, 659-665, 2004.

Sutherland, M. D. and Wells, J. W.: A re-examination of Indian and Loblolly turpentines, J. Org. Chem., 21(11), 1272-1275, 1956.

Tchoumbougnang, F., Zollo, P. H. A., Avlessi, F., Alitonou, G. A., Sohounhloue, D. K., Ouamba, J. M., Tsomambet, A., OkemyAndissa, N., Dagne, E., Agnaniet, H., Bessiere, J. M., and Menut, C.: Variability in the chemical composition of the essential oils of five Ocimum species from Tropical African area, J. Essent. Oil Res., 18(2), 194-199, 2006.

US EPA, M.1.: Estimation Programs Interface Suite for Microsoft Windows, AOPWIN v.1.92, United States Environmental Protection Agency, Washington D.C., USA, 2000.

Warneke, C., de Gouw, J. A., Lovejoy, E. R., Murphy, P. C., Kuster, W. C., and Fall, R.: Development of proton-transfer ion trap-mass spectrometry: On-line detection and identification of volatile organic compounds in air, J. Am. Soc. Mass Spectr., 16, 1316-1324, 2005a.

Warneke, C., de Gouw, J. A., Goldan, P. D., Kuster, W. C., Shao, M., Lovejoy, E. R., Fall, R., and Fehsenfeld, F. C.: Online volatile organic compound measurements using a newly developed protontransfer ion-trap mass spectrometry instrument during New England Air Quality Study - Intercontinental Transport and Chemical Transformation 2004: Performance, intercomparison, and compound identification, Environ. Sci. Technol., 39, 5390-5397, 2005b.

Werker, E., Putievsky, E., Ravid, U., Dudai, N., and Katzir, I.: Glandular hairs, secretory cavities, and the essential oil in leaves of tarragon (Artemisia dracunculus L.), Journal of Herbs, Spices 
and Medicinal Plants, 4(3), 19-32, 1994.

Werner, R. A.: Aggregation behaviour of the beetle Ips gradicollis in response to host-produced attractants, J. Insect Physiol., 18, 423-437, 1972.

Werner, R. A.: Toxicity and repellency of 4-allylanisole and monoterpenes from white spruce and tamarack to the spruce beetle and eastern larch beetle (Coleoptera: Scolytidae), Environ. Entomol., 24, 372-379, 1995.
Williams, B. J., Goldstein, A. H., Kreisberg, N. M., and Hering, S. V.: An in-situ instrument for speciated organic composition of atmospheric aerosols: Thermal desorption Aerosol GC/MS-FID (TAG), Aerosol Sci. Tech., 40, 627-638, 2006.

Yoshida, S.: Biosynthesis and conversion of aromatic amino acids in plants, Ann. Rev. Plant Physio., 20, 41-62, 1969.

Zavarin, E., Cobb Jr., F. W., Bergot, J., and Barber, H. W.: Variation in the Pinus ponderosa needle oil with season and needle age, Phytochemistry, 10, 3107-3114, 1971. 